\title{
COMSA V. CANADA (N.P.B.): The Right to a Timely Post-Revocation Hearing
}

\author{
NATHAN J. WHITLING
}

\section{INTRODUCTION}

The recent decision of Moreau J. of the Alberta Court of Queen's Bench in Comsa v. Canada (N.P.B.)' raises serious questions regarding the constitutionality of certain aspects of the parole suspension and revocation regime created by the Corrections and Conditional Release Act ${ }^{2}$ and the Corrections and Conditional Release Act Regulations. ${ }^{3}$ Under the interpretation of s. 163(3) of the Regulations enunciated by Moreau J., it would appear that suspended parolees who are incarcerated in remand facilities following their arrest have no legally protected right to post-suspension hearings unless and until government officials choose to exercise an unfettered statutory discretion to transfer them to the correctional facilities at which their sentences are to be served. Although Moreau J. noted that the operation of this regime "could lead to abuses" by government officials, she declined to consider the constitutional implications of this situation since no Charter ${ }^{4}$ challenge had been filed in the proceedings before her. ${ }^{5}$ It is the purpose of this comment to consider the merits of the Charter challenge that was not brought in Comsa.

\section{FACTS OF COMSA}

Stefan Hadrian Comsa had been sentenced to a term of imprisonment of six years commencing 6 January 1997. On 10 April 2000, he was granted full parole by the National Parole Board. Shortly after his release, on 15 June 2000, he was arrested and charged with two new offences. Upon his arrest, Comsa was incarcerated in the Edmonton Remand Centre, a provincial remand facility. On 16 June 2000, pursuant to s. 135(1) of the Act, a Warrant of Apprehension and Suspension of Full Parole was issued against him by his parole officer. A week later, on 23 June 2000, pursuant to $s$. 135(3)(b), ${ }^{6}$ Comsa's case was referred to the National Parole Board for a decision with respect to the revocation of his parole. Comsa remained at the Edmonton Remand Centre for several weeks, and was then transferred to Bowden Institution, a federal penitentiary, on 12 July 2000 , pursuant to s. $135(2)$. On 23 August 2000 , a stay of proceedings was entered by the Crown in respect of the 15 June 2000 charges.

Associate, Parlee McLaws, Edmonton, Alberta. The author wishes to thank Peter Shipanoff for his contributions to this comment.

Comsa v. Canada (N.P.B.) (2000), 282 A.R. 108 (Q.B.) [hereinafter Comsa].

Corrections and Conditional Release Act, S.C. 1992, c. 20 [hereinafter $A c t$ ].

Corrections and Conditional Release Regulations. SOR/92-620 [hereinafter Regulations].

Canadian Charter of Rights and Freedoms, Part I of the Constitution Act, 1982, being Schedule B to the Canada Act 1982 (U.K.), 1982, c. 11.

Comsa, supra note 1 at 116.

In Comsa at 110, para. 4, Moreau J. states that the referral occurred under s. 135(4) of the Act, but clearly intended to refer to the applicable s. 135(3)(b). 
On 13 September 2000, the Board decided to revoke Comsa's parole. Despite his request to be accorded a post-suspension hearing and to be represented by counsel, the Board's decision was rendered in his absence.

Comsa filed an application for habeas corpus on 2 October 2000, arguing that the Board had failed to accord him a post-suspension hearing within the 90-day limitation period reflected in s. 163(3) of the Regulations as adopted in s. 135(5) of the Act. This application was based primarily upon Moreau J.'s earlier decision in Lyding v. . $^{7}$

Two days after the filing of his habeas corpus motion, Comsa was advised by the Board that he would be accorded a new post-suspension hearing on 6 October 2000, being the same date at which his habeas corpus motion was to be heard by Moreau J.

At the hearing, Crown counsel argued that since Comsa had not been transferred from the Edmonton Remand Centre to the Bowden Institution until 12 July 2001, the 90-day time period contained in s. 163(3) of the Regulations did not start to run until that date. As such, the revocation hearing scheduled for later that afternoon met the Board's obligations under the Act. Section 163(3) of the Regulations reads:

Where the case of an offender has been referred to the Board pursuant to subsection 135(4) or (5) of the Act, and unless an adjournment of the review is granted by the Board at the offender's request, the Board shall render its decision within 90 days after the date of the referral, or the date of admission of the offender to a penitentiary or to a provincial correctional facility where the sentence is to be served in such a facility, whichever date is the later [emphasis added].

Justice Moreau accepted the Crown's argument, and held as follows:

I note that there is a strict time period prescribed in s. 135(3)(b) of the Act for the referral of a case to the Board where an offender serving a sentence of two years or more, namely "within $\mathbf{3 0}$ days after the recommitment or such shorter period as the Board directs" [emphasis in original]. Counsel were unable to direct me to any similar time period applying to the admission of an offender to a penitentiary or provincial correctional facility where the sentence is to be served in such a facility. I also note that the language of s. $135(3)$ (b) is very clear in calculating the time period, namely "within 30 days after the recommitment". Similar language was not used in regulation 163(3). There is no constitutional challenge before me to the regulation. Although as counsel for Comsa argues, the absence of a time limit within which a suspended parolee is to be admitted to a penitentiary or provincial correctional facility where his [or her] sentence is to be served could lead to abuses if ... he or she is incarcerated in remand facilities, I am mindful that the drafters of the Regulations had the opportunity to insert wording akin to s. 135(3)(b) in s. 163(3) of the regulation and did not. In this case, Comsa was admitted to Bowden Institution on July 12,2000. In my view, it cannot be argued on the evidence before me that he was an inmate of Bowden Institution during the period prior to his admission to that penitentiary and temporarily outside the penitentiary within the meaning of s. 2(1) of the Act as argued by his counsel. I note that he [was] released on full parole from Grierson Centre in Edmonton. 
Accordingly, I am of the view that the 90 day period prescribed in s. 163(3) of the Regulations has not expired. ${ }^{8}$

It is difficult to argue with the above interpretation enunciated by Moreau J. Essentially, she held that the language of s. 163(3) means what it says - the 90-day time period starts to run either from the date of the referral, or from the date of the transfer, whichever date is the later. In other words, the 90-day time period prescribed in $s$. 163(3) does not start to run unless and until the prisoner is transferred from the shortterm remand facility in which he is being held to the long-term facility at which the sentence is to be served.

The implications of this point are grave. As Moreau J. noted, the absence of any set time period within which the transfer of an inmate must occur creates opportunities for abuse. The Board and its designates may order the transfer after 30 days, or after six months, or not at all. The provision governing the exercise of this discretion is s. 135(2) of the Act:

A person designated pursuant to subsection (1) may, by warrant, order the transfer to penitentiary of an offender who is recommitted to custody pursuant to subsection (1) in a place other than a penitentiary [emphasis added].

It is difficult to understand why s. 163(3) reads the way it does. By rendering the commencement of the 90-day time period contingent upon the exercise of the discretion contained in s. 135(2), the provision appears to reflect the view that so long as a suspended parolee is merely imprisoned in a remand facility, the nature of his deprivation of liberty does not give rise to any constitutional right to a hearing within a reasonable time. Such a right only arises once the prisoner has been transferred to the long-term facility at which the balance of his sentence is to be served. This view is ironic given that it has been recognized on numerous occasions that the conditions of detention in short-term remand facilities such as the Edmonton Remand Centre are far more oppressive than those existing in federal penitentiaries. ${ }^{9}$

\section{CHARTER ISSUES}

It is now clearly the law that the liberty interests at stake in parole revocation proceedings attract scrutiny under $\mathrm{s} .7$ of the Charter.$^{10}$ However, this was not always the case. In the 1976 case of Mitchell v. R.," the Supreme Court of Canada held that since parole is a mere privilege and not a right, s. 2(e) of the Canadian Bill of Rights ${ }^{12}$

8 Comsa, supra note 1 at para. 27.

"R. v. Wust, [2000] 1 S.C.R. 455 at paras. 28 and $41 ; R$ v. Buggins, [2002] A.B.Q.B. 90 at para. 30; R. v. Kravchov, [2002] O.J. No. 2172 (Ont. C.J.), online: QL (OJ); R. v. A.D., [2001] A.B.Q.B. 905 at 10-22; R. v. McDonald (1998), 127 C.C.C. (3d) 57 (Ont. C.A.); R. v. Rezaie (1996), 112 C.C.C. (3d) 97 (Ont. C.A.) at 104. 
has no application to parole revocation proceedings under the old Parole Act. ${ }^{13}$ At page 588, Martland J. said:

The appellant also relies upon s. 2(e) of the Bill of Rights, which provides that no law of Canada shall be construed or applied so as to deprive a person of the right to a fair hearing in accordance with the principles of fundamental justice for the determination of his rights and obligations. In the McCaud case [[1965] I C.C.C. 168], Spence J., whose view was adopted unanimously on appeal, held that the provisions of $s .2(e)$ do not apply to the question of the revocation of parole under the provisions of the Parole Act.

The appellant had no right to parole. He was granted parole as a matter of discretion by the Parole Board. He had no right to remain on parole. His parole was subject to revocation at the absolute discretion of the Board.

Chief Justice Laskin, Spence and Dickson JJ. vigorously dissented from Martland J.'s decision in Mitchell. In their view, the majority's characterization of the liberty interests of a parolee as a mere privilege was impossible to reconcile with the well-established rule that accorded all persons the right to be heard, even when mere proprietary interests were at stake. ${ }^{14}$ Chief Justice Laskin then went on to state that, in his view, the parole revocation regime at issue before him was contrary to s. 2(e) and, indeed, "tyrannical." 15 This conclusion was based in part upon his observation that there existed no obligation for the Board to conduct a post-suspension hearing within a reasonable time. Instead, the timeliness of the hearing was left to the sole and arbitrary discretion of the Board:

As in the Howarth case [Howarth v. Canada (N.P.B.), [1976] I S.C.R. 453], the Board gave no reason for its suspension and for its revocation of parole. Its position there, as here, was that it is not obliged to give any reason, that it has an absolute discretion to determine whether or not to suspend parole or to revoke it, that it is not amenable to court process, whether by review in the Federal Court or through habeas corpus, and that even if, as here, it suspends parole on the eve of the expiry of sentence, it is immune from review albeit revocation of parole takes place beyond the expiry date of January I, 1974. I should add that counsel for the respondent conceded that the Board might dally for an undetermined period before deciding to revoke parole where it was suspended before the expiry date of the sentence. He advanced the suggestion, however, that the Court might hold the Board 10 a reasonable period. Certainly, the Act places no time limit on the Board, and if its powers are as arbitrary as has been contended by its counsel both in Howarth and here, I see no basis for checking it in this respect if it cannot be checked in other, even more important, respects.

The plain fact is that the Board claims a tyrannical authority that I believe is without precedent among administrative agencies empowered to deal with a person's liberty. It claims an unfettered power to deal with an inmate, almost as if he were a mere puppet on a string. What standards the statute indicates are, on the Board's contentions, for it to apply according to its appreciation and without accountability to the Courts. Its word must be taken that it is acting fairly, without it being obliged to

Parole Act, S.C. 1968 , c. 38.

Mitchell, supra note 11 at 574-85.

lbid. at 577. 
give the slightest indication of why it was moved to suspend or revoke parole. All this is said to be expressed or found in the Parole Act, and is said, moreover, to be this Court's view of the Board's powers under its decision in the Howarth case. ${ }^{16}$

Chief Justice Laskin's dissent in Mitchell has proven influential in the Charter era. In the landmark case of Singh v. Canada, Wilson J. held that its reasoning is now to be preferred over that of the majority. ${ }^{17}$ The Court in Singh went on to strike down the provisions of the Immigration Act, $1976,{ }^{18}$ since they failed to accord to refugee claimants any right to a fair hearing at which to answer the arguments raised against them. ${ }^{19}$ Similarly, in $R$. v. Swain,$^{20}$ the absence of any right to a hearing was fatal to the former section of the Criminal Code ${ }^{21}$ that required the automatic detention of persons found to be not guilty of a criminal offence by reason of insanity.

Of all the principles of fundamental justice enshrined in the Charter, perhaps the most fundamental of all is the rule which accords every prisoner the right to a hearing at which to challenge the validity of his detention. ${ }^{22}$ Based upon the interpretation articulated by Moreau J. in Comsa, it is difficult to perceive the observance of this right in the parole revocation regime created by the Act and Regulations. Although it may well be the case that the Board will generally exercise its discretion to transfer the

Ibid. at 576-77 [emphasis added].

Singh v. Canada (Employment and Immigration), [1985] I S.C.R. 177 at 209 [hereinafter Singh]:

I do not think this kind of analysis [by Martland J.] is acceptable in relation to the Charter. It seems to me rather that the recent adoption of the Charter by Parliament and nine of the ten provinces as part of the Canadian constitutional framework has sent a clear message to the courts that the restrictive attitude which at times characterized their approach to the Canadian Bill of Rights ought to be re-examined. I am accordingly of the view that the approach taken by Laskin C.J. dissenting in Mitchell is to be preferred to that of the majority as we examine the question whether the Charter has any application to the adjudication of rights granted to an individual by statute.

Immigration Act, 1976, S.C. 1976-77, c. 52.

Singh, supra note 17 at $220-23$.

R. v. Swain, [1991] I S.C.R. 933 at 1009:

The automatic detention required under s. 542(2) clearly deprives the appellant of his right to liberty. However, if this deprivation is in accordance with the principles of fundamental justice, there will be no limitation of his rights under s. 7 of the Charter. As was stated in [Reference re Motor Vehicle Act (British Columbia), s. 94(2), [1985] 2 S.C.R. 486], supra, at pp. 503-4, the principles of fundamental justice, while not limited to "natural justice", require at least those procedural safeguards. Because s. 542(2) provides for no hearing or other procedural safeguards whatsoever, I need not proceed any further to conclude that the deprivation of liberty is not in accordance with the principles of fundamental justice [emphasis added].

Criminal Code, R.S.C. 1970, c. C-34, s. 542(2).

Magna Carta, 1297 (U.K.), 25 Edw. 1, c. 29:

No Freeman shall be taken, or imprisoned, or be disseised of his Freehold, or Liberties, or free Customs, or be outlawed, or exiled, or any other wise destroyed; nor will We pass upon him, nor condemn him, but by lawful judgment of his Peers, or by the Law of the Land. We will sell to no man, we will not deny or defer to any man either Justice or Right.

In The King v. Gaskin (1799), 101 E.R. 1349 (K.B.) at 1350, Lord Kenyon said:

It is to be found at the head of our criminal law, that every man ought to have an opportunity of being heard before he is condemned: and I should tremble at the consequences of giving way to this principle. 
inmate within a reasonable time, there appears to exist no rule of law requiring it to do so. $^{23}$

In Mitchell, Laskin C.J.C. described the parole revocation regime under the old Parole Act as "tyrannical" because "the Board might dally for an undetermined period before deciding to revoke parole where it was suspended before the expiry date of the sentence." 24 The only difference between the regime created by the present statute and the "tyrannical" regime at issue in Mitchell is that the authority to "dally for an undetermined period" has now been subsumed within the authority to transfer the suspended parolee to the institution at which his sentence is to be served. The fundamental problem still remains - there is no legal requirement that the Board hold a post-suspension hearing within a reasonable time from the date of the suspension of parole, or at all. Theoretically, government officials could suspend a parolee's parole, incarcerate him in a remand facility indefinitely, and never accord to him the right to a post-suspension hearing at which to challenge the legality of his imprisonment. ${ }^{25}$

Comsa also raises issues under s. 9 of the Charter. Since there are no legal criteria of any kind which appear to govern the exercise of the discretion conferred by $\mathbf{S}$. 135(2), ${ }^{26}$ the Act empowers state officials to ensure the continued detention and imprisonment of suspended parolees on purely arbitrary grounds.

It is difficult to believe that the absence of a clear right to a hearing can be cured by trusting state officials to exercise their discretion in good faith and in the best interests of the prisoner. As McLachlin J. (as she then was) said in R. v. Zundel, [1992] 2 S.C.R. 731 at 773:

The whole purpose of enshrining rights in the Charter is to afford the individual protection against even the well-intentioned majority. To justify an invasion of a constitutional right on the ground that public authorities can be trusted not to violate it unduly is to undermine the very premise upon which the Charter is predicated.

25 Though of course, should the incarceration extend beyond the expiry of the sentence, the incarceration would be rendered illegal and give rise to a right of release by way of habeas corpus. In R. v. Hufsky, [1988] I S.C.R. 621 at 632-33, the Supreme Court of Canada declared police check-stops to be contrary to s. 9 of the Charter (though justified under s. 1) as follows:

The next issue with respect to the appellant's contention based on s. 9 of the Charter is whether the detention resulting from the random stop for the purposes of the spot check procedure was arbitrary within the meaning of s. 9. Section 189a(1) of the Highway Traffic Act empowers a police officer who is in the lawful execution of his duties and responsibilities to require the driver of a motor vehicle to stop. It does not specify that there must be some grounds or cause for stopping a particular driver but on its face leaves the choice of the drivers to be stopped to the discretion of the officer. In carrying out the purposes of the spot check procedure, including the observation of the condition or "sobriety" of the driver, the officer was clearly in the lawful execution of his duties and responsibilities. Although authorized by statute and carried out for lawful purposes, the random stop for the purposes of the spot check procedure nevertheless resulted, in my opinion, in an arbitrary detention because there were no criteria for the selection of the drivers to be stopped and subjected to the spot check procedure. The selection was in the absolute discretion of the police officer. A discretion is arbitrary if there are no criteria, express or implied, which govern its exercise. The appellant was therefore arbitrarily detained, within the meaning of s. 9 of the Charter, as a result of the random stop for the purposes of the spot check procedure, and the second constitutional question should accordingly be answered in the affirmative [emphasis added]. 
Finally, the interpretation enunciated in Comsa may suggest that s. 163(3) of the Regulations is ultra vires the authority conferred upon the Governor in Council by the Act. The language of s. 135(5) appears to indicate that Parliament only intended to confer upon the Governor in Council the authority to prescribe a time period from the date of the referral of the suspended parolee's case to the Board ${ }^{27}$ (being an event which must occur within 30 days from the date of the parolee's recommitment). Over and above prescribing a time period, however, the Governor in Council has purported to suspend the commencement of that time period until state officials choose to exercise the discretion conferred upon them by s. 135(2). It seems unlikely that s. 135(5) was intended to confer upon the Governor in Council the authority to indefinitely delay the accrual of a suspended parolee's right to a post-revocation hearing.

\section{CONCLUSion}

The Comsa case appears to identify a loophole in Canada's current parole suspension and revocation regime. Theoretically, government officials could use this loophole to imprison a suspended parolee indefinitely, without ever according him a postsuspension hearing. Although such an extreme circumstance is not likely to occur, the absence of any clearly identifiable limitation period creates a real potential for excessive bureaucratic delays, and an inconsistent observance of the principles of fundamental justice.

The Board shall. on the referral to it of the case of an offender serving a sentence of two years or more, review the case and, within the period prescribed by the regulations. unless the Board grants an adjournment at the offender's request,

(a) cancel the suspension, where the Board is satisfied that, in view of the offender's behaviour since release, the offender will not, by reoffending before the expiration of the offender's sentence according to law, present an undue risk to society;

(b) where the Board is not satisfied as provided in paragraph (a). terminate the parole or statutory release of the offender if it was suspended by reason of circumstances beyond the offender's control or revoke it in any other case; or

(c) where the offender is no longer eligible for the parole or entitled to be released on statutory release, terminate or revoke it [emphasis added]. 